\title{
Dissection of the radical reactions linked to fetal hemoglobin reveals enhanced pseudoperoxidase activity
}

\author{
Khuanpiroon Ratanasopa ${ }^{1}$, Michael Brad Strader ${ }^{2}$, Abdu I. Alayash ${ }^{2}$ and Leif Bulow ${ }^{1 *}$ \\ ' Pure and Applied Biochemistry, Department of Chemistry, Lund University, Lund, Sweden \\ ${ }^{2}$ Laboratory of Biochemistry and Vascular Biology, Center for Biologics Evaluation and Research, Food and Drug Administration, Silver Spring, MD, USA
}

Edited by:

Magnus Gram, Lund University,

Sweden

Reviewed by:

Scarlet Y. Shi, Medical College of Wisconsin, USA

Artak Tovmasyan, Duke University, USA

\section{*Correspondence:}

Leif Bulow, Pure and Applied Biochemistry, Department of Chemistry, Lund University, Getingevagen 60, PO Box 124, 22100 Lund, Sweden

e-mail: leif.bulow@tbiokem.lth.se
In the presence of excess hydrogen peroxide $\left(\mathrm{H}_{2} \mathrm{O}_{2}\right)$, ferrous $\left(\mathrm{Fe}^{+2}\right)$ human hemoglobin $(\mathrm{Hb})(\alpha 2 \beta 2)$ undergoes a rapid conversion to a higher oxidation ferryl state $\left(\mathrm{Fe}^{+4}\right)$ which rapidly autoreduces back to the ferric form $\left(\mathrm{Fe}^{+3}\right)$ as $\mathrm{H}_{2} \mathrm{O}_{2}$ is consumed in the reaction. In the presence of additional $\mathrm{H}_{2} \mathrm{O}_{2}$ the ferric state can form both ferryl $\mathrm{Hb}$ and an associated protein radical in a pseudoperoxidative cycle that results in the loss of radicals and heme degradation. We examined whether adult $\mathrm{HbA}(\beta 2 \alpha 2)$ exhibits a different pseudoenzymatic activity than fetal $\mathrm{Hb}(\gamma 2 \alpha 2)$ due to the switch of $\gamma$ to $\beta$ subunits. Rapid mixing of the ferric forms of both proteins with excess $\mathrm{H}_{2} \mathrm{O}_{2}$ resulted in biphasic kinetic time courses that can be assigned to $\gamma / \beta$ and $\alpha$, respectively. Although there was a 1.5 fold increase in the fast reacting $\gamma / \beta$ subunits the slower reacting phases (attributed to $\alpha$ subunits of both proteins) were essentially the same. However, the rate constant for the auto-reduction of ferryl back to ferric for both proteins was found to be $76 \%$ higher for $\mathrm{HbF}$ than $\mathrm{HbA}$ and in the presence of the mild reducing agent, ascorbate there was a 3-fold higher reduction rate in ferryl $\mathrm{HbF}$ as opposed to ferryl $\mathrm{HbA}$. Using quantitative mass spectrometry in the presence of $\mathrm{H}_{2} \mathrm{O}_{2}$ we found oxidized $\gamma / \beta$ Cys93, to be more abundantly present in $\mathrm{HbA}$ than $\mathrm{HbF}$, whereas higher levels of nitrated $\beta$ Tyr35 containing peptides were found in $\mathrm{HbA}$ samples treated with nitrite. The extraordinary stability of $\mathrm{HbF}$ reported here may explain the evolutionary advantage this protein may confer onto co-inherited hemoglobinopathies and can also be utilized in the engineering of oxidatively stable Hb-based oxygen carriers.

Keywords: hemoglobins, fetal blood, peroxidases, kinetics, spectrophotometry, quantitative mass spectrometry

\section{INTRODUCTION}

Fetal hemoglobin $(\mathrm{HbF})$ is the main oxygen carrier protein in the human fetus during the last 7 months of development in the uterus and remains the dominating $\mathrm{Hb}$ in the newborn until the age of approximately 6 months. In contrast to the adult form ( $\mathrm{HbA}$ ), which has a quaternary $\alpha_{2} \beta_{2}$ structure, $\mathrm{HbF}$ is composed of two alpha and two gamma chains, commonly denoted as $\alpha_{2} \gamma_{2}$. Even though the overall structure shows strong similarities with that of $\mathrm{HbA}$, the two Hbs exhibit some important differences in their biophysical properties, such as $\mathrm{O}_{2}$ binding affinity (Hofmann and Brittain, 1996); and binding kinetics to other ligands (Engel et al., 1969; Manca and Masala, 2008). In a healthy adult, $\mathrm{HbF}$ levels are very low, less than $0.6 \%$, but can be elevated in pregnant women. HbF levels are also enhanced under some specific conditions, notably in $\beta$-thalassemia, hereditary persistence of fetal hemoglobin (HPFH) and sickle cell anemia (SCD) (Forget, 1998; Olsson et al., 2010). Due to its ability to solubilize $\mathrm{HbS}$ polymers, switching the synthesis of $\mathrm{HbF}$ within affected patients RBCs has been shown to have an anti-sickling therapeutic potential in sickle cell disease (SCD). Moreover, a recent study demonstrates that an increase of HbF levels in sickle cell anemia patients helps to reduce kidney damages (Risso et al., 2012). Therefore, several efforts are currently (Reeder, 2010; Akinsheye et al., 2011) being undertaken to identify new active substances that can induce $\mathrm{HbF}$ in $\mathrm{SCD}$ or $\beta$-thalassemia patients (Bianci et al., 2007). However, HbF levels can be elevated also under other and more normal conditions, e.g., in adults that have been exposed to high altitude hypoxia often exhibit higher expression levels (Lebensburger et al., 2011).

$\mathrm{Hb}$ becomes toxic if it is released from erythrocytes. This toxicity is largely caused by oxidative reactions linked to the $\mathrm{Hb}$ molecule, which in turn results in damage to surrounding tissues, proteins, nucleic acids and lipids (Alayash, 2004; Bianci et al., 2007). Due to the structural differences between $\mathrm{HbA}$ and $\mathrm{HbF}$, the kinetics of the radical reactions associated with these globins is dissimilar. For instance, $\mathrm{HbF}$ has been proposed to be one of the main causative agents behind the inflammatory damage of the placenta in preeclampsia (Olsson et al., 2010). HbF has therefore been suggested to be, either alone or together with alpha-1-microglobulin (A1M), most valuable as a biomarker for prediction of preeclampsia (Anderson et al., 2012). It is therefore, essential to develop a better understanding of the radical reactions associated particularly with $\mathrm{HbF}$ in order to design against or for these properties.

It is well known that cell-free $\mathrm{Hb}$ molecules are susceptible to and often are involved in various oxidative reactions, for instance, when $\mathrm{Hb}$ is exposed to $\mathrm{H}_{2} \mathrm{O}_{2}$-rich environments (Kvist et al., 2007; Olsson et al., 2012). The reaction between $\mathrm{Hb}$ and $\mathrm{H}_{2} \mathrm{O}_{2}$ 
may lead to an irreversible loss of $\mathrm{Hb}$ activity, and ferryl $\mathrm{Hb}$ which is formed as an intermediate, is a highly reactive species which together with other $\mathrm{Hb}$ oxidation products (i.e., heme) may contribute to inflammatory responses (Baek et al., 2012; Belcher et al., 2014). The reaction between ferrous $\mathrm{Hb}$ and $\mathrm{H}_{2} \mathrm{O}_{2}$ results in ferryl heme $\left(\mathrm{Fe}^{4+}\right)$ formation without generating a protein based free radical. The presence of the highly oxidizing ferryl heme species may ultimately lead to heme degradation and heme-protein crosslinking products (Reeder et al., 2008a; Alayash, 2014). On the other hand, the reaction with ferric $\mathrm{Hb}$ results in oxoferryl $\left(\mathrm{Fe}^{4+}\right)$ and protein- or prosthetic group associated free radicals. The oxyferryl may also react further with excess $\mathrm{H}_{2} \mathrm{O}_{2}$, yielding ferric $\mathrm{Hb}$ and $\mathrm{H}_{2} \mathrm{O}$ (Reeder et al., 2008a). This activity is referred to as "pseudoperoxidative" because the $\mathrm{Hb}$ is unable to harness its radicals like other classical oxidases, such as cytochrome oxidase, and prostacyclin synthases (Stubbe and Riggs-Gelasco, 1998). Therefore, the reaction involving ferric $\mathrm{Hb}$ can act as a competitor to the reaction between oxyHb and $\mathrm{H}_{2} \mathrm{O}_{2}$ to limit the levels of heme degradation products as well as to reduce the maximal levels of ferryl $\mathrm{Hb}$ (Reeder et al., 2008a). Moreover, investigation of the contribution of individual $\mathrm{Hb}$ subunits to the overall redox activity of $\mathrm{Hb}$ and their relative stabilities under oxidative stress revealed that $\alpha$ unlike $\beta$ and $\gamma$ are able to reduce ferryl $\mathrm{Hb}$ possibly through an internal electron pathway, involving Tyr42 (Reeder et al., 2008a; Mollan et al., 2013).

In this study, the pseudoperoxidative activity of $\mathrm{HbF}$ was compared with that of $\mathrm{HbA}$. $\mathrm{Hb}$ can undergo a range of oxidative reactions. In order to facilitate the interpretation and analysis of the obtained experimental data, the main focus was put on the ferric form of $\mathrm{Hb}$ We show that ferric $\mathrm{HbF}$ can react rapidly with $\mathrm{H}_{2} \mathrm{O}_{2}$ to exert a faster association rate constant relative to HbA. However, both the autoreduction and ascorbate mediated reduction rates were faster for $\mathrm{HbF}$. Kinetics of ferryl reduction by ascorbate demonstrated that $\mathrm{HbF}$ has a lower $K_{D}$ value for the high affinity pathway. The faster turnover rate of $\mathrm{HbF}$ is also demonstrated by the reaction between oxyHb and nitrite. To expand on these studies, we performed a mass spectrometry characterization to elucidate how different residues in the $\alpha, \beta$, and $\gamma$ globins respond to $\mathrm{H}_{2} \mathrm{O}_{2}$ exposure. By combining the experimental results with existing structural information, an anti-oxidative role of $\mathrm{HbF}$ can be envisaged in vivo. Immediate implications in clinical settings as well as in the design of functional and stable Hb-based oxygen carriers (HBOCs) can be anticipated (Alayash, 2014).

\section{MATERIALS AND METHODS MATERIALS}

$\mathrm{HbA}$ and $\mathrm{HbF}$ purified from healthy volunteers and cord blood, respectively, were kindly provided by Prof Bo Akerstrom at the Biomedical Center, Lund University. Both the oxy and the ferric forms of the proteins were examined. Ferric $\mathrm{Hb}$ was prepared by adding $1.5 \mathrm{M}$ excess of potassium ferricyanide $\mathrm{K}_{3}\left[\mathrm{Fe}(\mathrm{CN})_{6}\right]$. The sample was incubated for 5 min under visible light and excess of ferri-ferrocyanide was then removed by filtration on a Sephadex G-25 column. All experiments were performed under aerobic conditions at $25^{\circ} \mathrm{C}$, if not otherwise specified.

\section{AUTOOXIDATION}

Oxyhemoglobin concentrations were measured spectrophotometrically at $523 \mathrm{~nm}$ using $7.12 \mathrm{mM}^{-1} \mathrm{~cm}^{-1}$ as molar extinction coefficient (Snell and Marini, 1988; Vandegriff et al., 2006). The autoxidation experiments were performed in $0.1 \mathrm{M}$ sodium phosphate buffer $\mathrm{pH} 7.4$ by monitoring the decrease of oxyHb over $48 \mathrm{~h}$. The autoxidation rate constants were obtained by fitting to a first order exponential equation (Strader et al., 2014).

\section{OXIDATION REACTIONS OF FERRIC HEMOGLOBIN WITH HYDROGEN PEROXIDE}

The oxidation of ferric $\mathrm{Hb}$ was monitored by a stopped-flow rapid mixing approach. The reaction between ferric $\mathrm{Hb}$ and $\mathrm{H}_{2} \mathrm{O}_{2}$ was thus performed under pseudo first order reaction conditions by placing $20 \mu \mathrm{M}$ of ferric $\mathrm{Hbs}$ and $\mathrm{H}_{2} \mathrm{O}_{2}$ at concentrations up to $1000 \mu \mathrm{M}$ in separate syringes. The two components were rapidly mixed and the time course of reaction was followed at $405 \mathrm{~nm}$ using the RX-2000 rapid kinetic accessory (Applied Photophysics Limited, United Kingdom). The time course was fitted to a double exponential equation. The rate constant of each reaction phase could then be obtained by linear regression and was plotted as a function of the hydrogen peroxide concentration.

\section{FERRYL HEMOGLOBIN REDUCTION BY ASCORBATE}

The ferryl $\mathrm{Hb}$ reduction study was performed according to a previously described method with slight modifications (Reeder et al., 2008a). Briefly, $20 \mu \mathrm{M}$ ferric $\mathrm{Hb}$ was placed in a cuvette, supplemented with $100 \mu \mathrm{M} \mathrm{H}_{2} \mathrm{O}_{2}$ to convert the globin to the ferryl form. $10 \mathrm{nM}$ of catalase was added to stop the reaction. Increasing concentrations of ascorbate were then added $(0-500 \mu \mathrm{M})$, and the formation of ferric $\mathrm{Hb}$ was monitored spectrophotometrically until the reaction was completed using an Agilent 8453 instrument. The time course of reaction at $405 \mathrm{~nm}$ was fitted to a double exponential equation using the Microsoft Excel Solver program. The set of obtained rate constants was then plotted vs. the ascorbate concentration, and the data were fitted to a double rectangular hyperpolar function (Reeder et al., 2008b).

\section{LIPOSOME OXIDATION}

One micro molar of ferric $\mathrm{Hb}$ in $20 \mathrm{mM}$ sodium phosphate buffer $\mathrm{pH} 7.4$ was incubated together with liposomes prepared by sonicating 23\% phosphatidylcholine in the same buffer. The final concentration of liposome was $200 \mu \mathrm{M}$. The formation of conjugated dienes was monitored over time at $234 \mathrm{~nm}$ using $\varepsilon_{234}=$ $2.5 \times 10^{4} \mathrm{M}^{-1} \mathrm{~cm}^{-1}$ (Egmond et al., 1976).

\section{OXYHEMOGLOBIN AND NITRITE}

Forty micro molar of oxyHb in $20 \mathrm{mM}$ sodium phosphate buffer pH 7.4 was rapidly mixed with a $1.0 \mathrm{mM}$ sodium nitrite solution in the stopped-flow using a RX-2000 rapid kinetic accessory provided by the manufacturer. Absorption spectra ranging from 450 to $700 \mathrm{~nm}$ were recorded every $15 \mathrm{~s}$ for $5 \mathrm{~min}$ with a scanning rate of $2880 \mathrm{~nm} / \mathrm{min}$ and $3 \mathrm{~nm}$ interval. The multispectra obtained were then analyzed by Convex Constraint Analysis program (CCA plus) (Perczel et al., 1991). By using default setting parameters, the reaction product components over the time were obtained. 


\section{COMPARATIVE ANALYSIS OF OXIDATIVE HOTSPOTS IN HbA AND HbF USING QUANTITATIVE PROTEOMICS}

The effects of $\mathrm{H}_{2} \mathrm{O}_{2}$ and $\mathrm{NaNO}_{2}$-mediated oxidation of key amino acids in "hotspots" within $\gamma / \beta$ and $\alpha$ subunits were investigated in both proteins.by a proteomic profiling study (Alayash, 2004; Jia et al., 2007; Pimenova et al., 2010). HbA and HbF stocks were treated with excess $\mathrm{K}_{3}\left[\mathrm{Fe}(\mathrm{CN})_{6}\right]$ to generate the ferric form of both proteins. Removal of $\mathrm{K}_{3}\left[\mathrm{Fe}(\mathrm{CN})_{6}\right]$ was accomplished using a G-25 Sephadex (Sigma) column. In one set of reactions, $10 \mu \mathrm{M}$ ferric $\mathrm{HbA}$ and $\mathrm{HbF}$ samples were treated with incremental doses $(0,100 \mu \mathrm{M}, 200 \mu \mathrm{M}, 300 \mu \mathrm{M}, 400 \mu \mathrm{M}$, and $500 \mu \mathrm{M})$ of $\mathrm{H}_{2} \mathrm{O}_{2}$. In a second set of reactions, $40 \mu \mathrm{M}$ ferrous $\mathrm{HbA}$ and $\mathrm{HbF}$ was treated with $1 \mathrm{mM} \mathrm{NaNO}_{2}$. Both experimental sets were incubated overnight in $20 \mathrm{mM}$ sodium phosphate buffer $\mathrm{pH}$ 7.4. All samples were processed, trypsinized and analyzed (in triplicate) by reverse phase liquid chromatography tandem mass spectrometry (RP LC/MS/MS) using an Easy nLC II Proxeon nanoflow HPLC system coupled online to a Q-Exactive Orbitrap mass spectrometer (Thermo Scientific) as previously described (Strader et al., 2014). Briefly, data were acquired using a top10 method (for $60 \mathrm{~min}$ ) dynamically choosing the most abundant precursors (scanned at $400-2000 \mathrm{~m} / \mathrm{z}$ ) from the survey scans for HCD fragmentation. The database search engine Mascot 2.4 (Matrix Sciences, London, UK) was utilized to identify oxidized version of "hotspot" peptides, by searching all MS/MS data against the Swiss-Prot Human database (release 2014_03; contains 542782 sequence entries) supplemented with porcine trypsin using the differential search parameters specified for detecting variable modifications including oxidation of methionine ( +16 daltons), cysteine $(+32$ and +48 daltons) and nitration of tyrosine $(+45$ daltons). Because all experimental samples were denatured and treated with iodoacetamide prior to trypsinization, an additional static search involving carbamidomethylation of cysteine was included to identify all unoxidized cysteine (not oxidized in presence of $\mathrm{H}_{2} \mathrm{O}_{2}$ ). The precursor ion mass tolerance was \pm $10 \mathrm{ppm}$ and the fragment ion mass tolerance was $\pm 0.025 \mathrm{Da}$. Mascot output files were analyzed using the software Scaffold 4.2.0 (Proteome Software Inc.) Scaffold filters were adjusted to only include peptide identifications that were accepted if they could be established at greater than $99.0 \%$ probability by the Peptide Prophet algorithm (Keller et al., 2002). This resulted in a false positive discover rate (FDR) of $0.1 \%$. Protein identifications were accepted if they could be established at greater than $95.0 \%$ probability and contained at least two identified peptides. Protein probabilities were assigned by the Protein Prophet algorithm (Nesvizhskii et al., 2003). Extracted ion chromatograms of the modified (and unmodified) version of tryptic peptides listed in Table 1 were used to quantify differences between HbA and HbF. For relative quantification, the ratio of each oxidized "hot spot" peptide was calculated based on the sum of the extracted ion chromatogram (XIC) peak area of all forms (oxidized and unmodified) to be $100 \%$. Hotspot residues used for comparisons included conserved residues found on $\beta, \gamma$, and $\alpha$ subunits (Jia et al., 2007).

\section{RESULTS}

$\mathrm{HbA}$ and HbF in the oxy-, deoxy-, ferric and ferryl forms all showed identical and typical absorption spectra associated with hemoglobins in the range 350-700 nm. For instance, for the oxyHbs a soret peak was easily identified at $415 \mathrm{~nm}$ and Q bands at 540 and $577 \mathrm{~nm}$, respectively (Figure 1). Cell-free Hb is rapidly oxidized outside the protective environment of the red blood cells. The autooxidation measurements were therefore directly

Table 1 | "Hotspot" modified amino acids identified in the reaction of hemoglobins with peroxide.

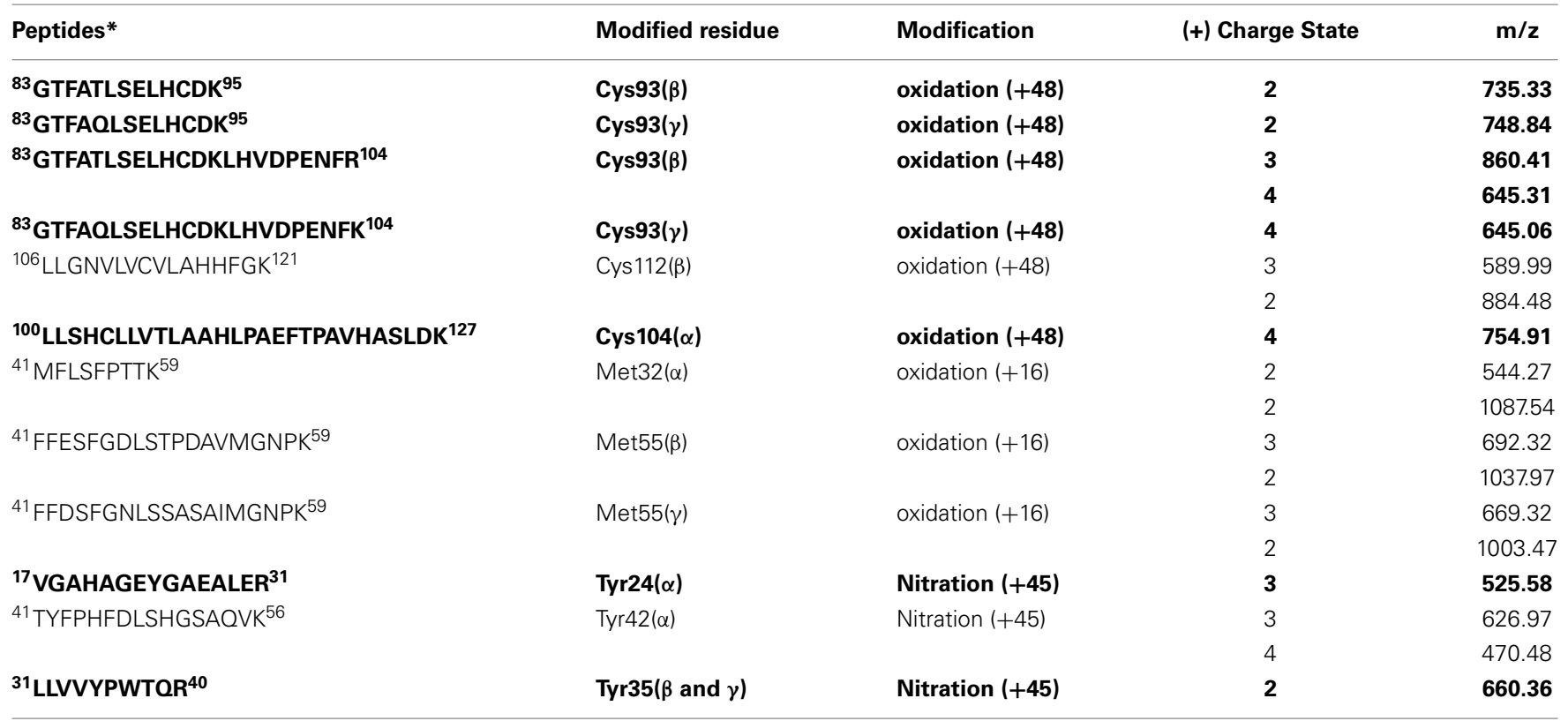

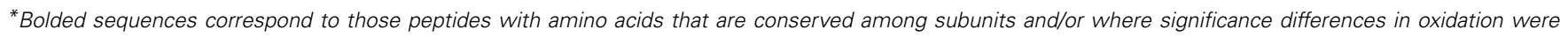
observed. 
comparable for the two hemoglobins and they exhibited similar autoxidation rates of $0.046 \mathrm{~h}^{-1}$ and $0.049 \mathrm{~h}^{-1}$ for $\mathrm{HbA}$ and $\mathrm{HbF}$, respectively. These values are close to reported autooxidation rates for human hemoglobins (Strader et al., 2014). To determine the oxidation rate of ferric $\mathrm{Hb}$ by $\mathrm{H}_{2} \mathrm{O}_{2}$, a set of experiments was

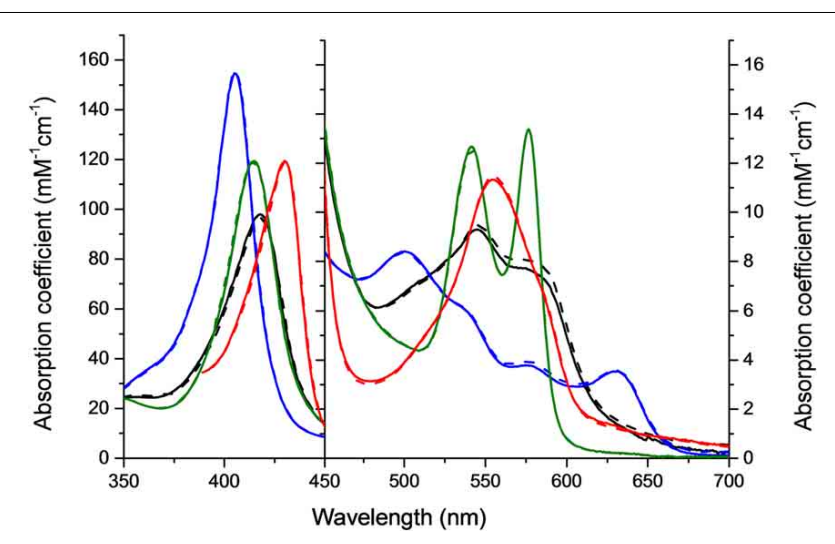

FIGURE 1 | Molar absorption coefficients of the four different $\mathrm{Hb}$ forms used in $0.1 \mathrm{mM}$ sodium phosphate buffer $\mathrm{pH} 7.4$ at $25^{\circ} \mathrm{C}$. Green, oxy; Red, deoxy; Blue, ferric; and Black, ferryl form. Solid lines represent $\mathrm{HbF}$ and dashed lines $\mathrm{HbA}$. carried out under pseudo first order reaction conditions. The time course of the drop in ferric Hb levels at $405 \mathrm{~nm}$ fitted best with a double exponential equation. By this fitting method, two rate constants were obtained, and assigned as $k_{\text {fast }}$ and $k_{\text {slow }}$, respectively. The set of rate constants was then plotted against the concentration of $\mathrm{H}_{2} \mathrm{O}_{2}$ resulting in a linear relationship as shown in Figure 2. The slope of the plot gives a second-order rate constant for the reaction between ferric $\mathrm{Hb}$ and $\mathrm{H}_{2} \mathrm{O}_{2}$. The $\mathrm{k}_{\text {fast }}$ of the reaction was found to be $=1.89 \times 10^{-4} \pm 0.01 \times 10^{-4} \mu \mathrm{M}^{-1} \mathrm{~s}^{-1}$ and $2.82 \times 10^{-4} \pm 0.03 \times 10^{-4} \mu \mathrm{M}^{-1} \mathrm{~s}^{-1}$ for $\mathrm{HbA}$ and $\mathrm{HbF}$, respectively. The $\mathrm{k}_{\text {slow }}$ of the reaction was found to be very similar for both hemoglobins, $5.72 \times 10^{-5} \pm 0.12 \times 10^{-5} \mu \mathrm{M}^{-1} \mathrm{~s}^{-1}$ and $6.08 \times 10^{-5} \pm 0.08 \times 10^{-5} \mu \mathrm{M}^{-1} \mathrm{~s}^{-1}$ for $\mathrm{HbA}$ and $\mathrm{HbF}$, respectively. These results can be assigned to the difference of oxidation between $\alpha$ and $\beta / \gamma$ chains. The oxidation rate of the $\gamma$ chain is thus $50 \%$ higher than the beta chain.

Similarly, the rate of ferryl $\mathrm{Hb}$ reduction was determined by adding a mild reducing agent, ascorbate (Figure 3 ). As can be seen in this figure, a biphasic time course can be clearly distinguished. For the fast rate constant, both hemoglobins exhibited a double rectangular hyperbolic behavior dependent on the concentration of ascorbate. This reaction profile has previously been reported for native $\mathrm{HbA}$ and some hemoglobin mutants (Reeder et al., 2008a). However, the slow rate constant displayed no sign of having double rectangular hyperbolic character. The fast rate
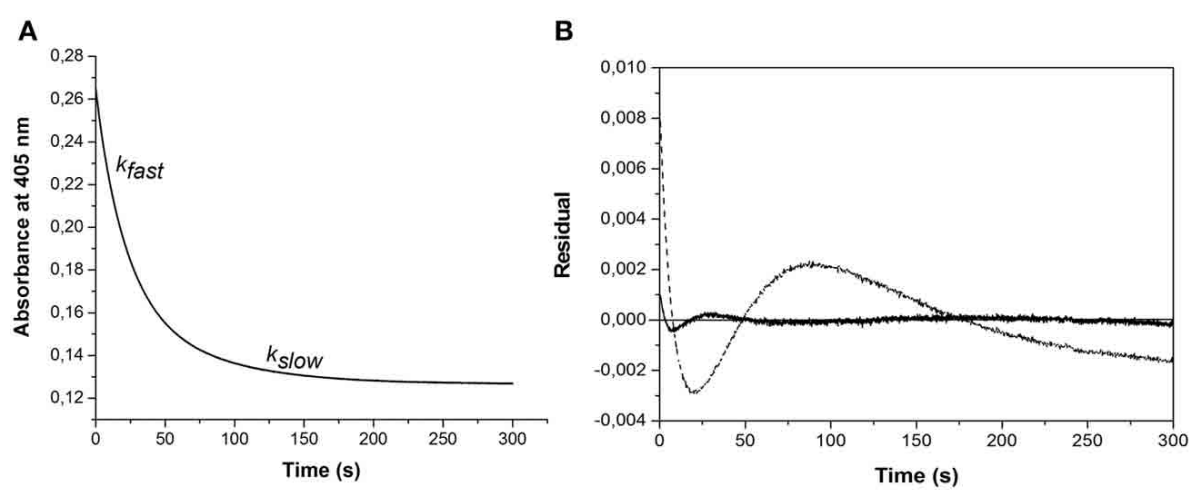

C

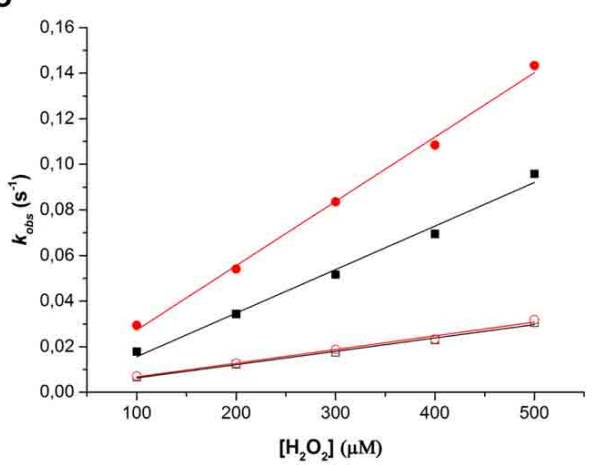

FIGURE 2 | Oxidation of ferric hemoglobin by hydrogen peroxide. The experiment was carried out under pseudo first order reaction conditions, where the concentration of $\mathrm{Hb}$ was kept constant at $10 \mu \mathrm{M}$ while varying the concentration of $\mathrm{H}_{2} \mathrm{O}_{2}(100-500 \mu \mathrm{M})$. (A) Represents an example of the time course for the reaction using $10 \mu \mathrm{M}$ ferric $\mathrm{HbA}$ and $500 \mu \mathrm{M}$ hydrogen peroxide monitored at $405 \mathrm{~nm}$. The time course was best fitted to a double exponential equation giving two rate constants, $k_{\text {fast }}$ and $k_{\text {slow, }}$ respectively. (B) Residuals from the fit of the time course to a single exponential (dashed line) and a double exponential (solid line) equation. (C) Shows plots of $\mathrm{k}_{\text {obs }}$ against $\mathrm{H}_{2} \mathrm{O}_{2}$ concentration used. (O): $\mathrm{k}_{\text {fast }} \mathrm{HbF}$, ( $k_{\text {fast }} \mathrm{HbA},(\mathrm{O})$ : k klow $\mathrm{HbF}$, and ( $\square$ ): kslow $\mathrm{HbA}$. Solid lines represent the linear regression function. 


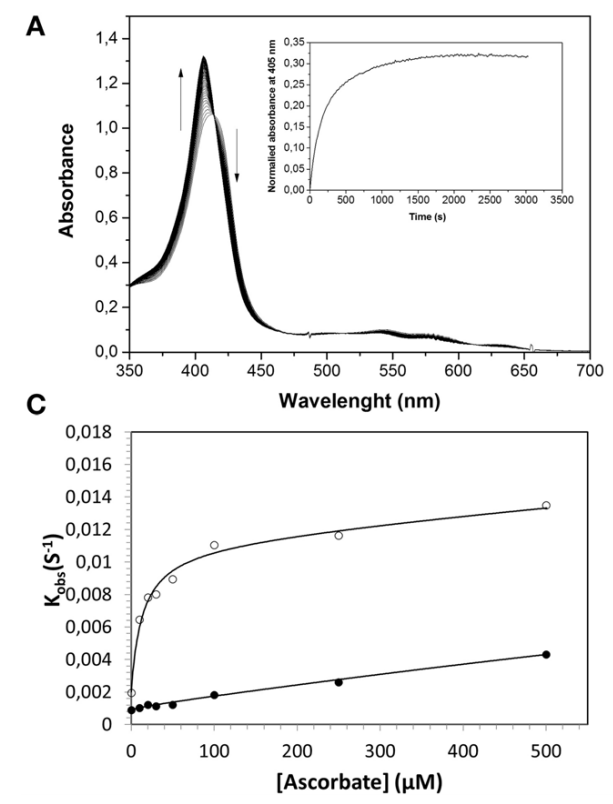

FIGURE 3 | Reduction of ferrylHb by ascorbate, illustrating the influence of increasing ascorbate concentrations on the reaction rate constants. Ferryl $\mathrm{HbF}(10 \mu \mathrm{M})$ was generated by adding hydrogen peroxide to ferric $\mathrm{Hb}$ at $\mathrm{pH}$ 7.4. Catalase was then supplemented to remove the excess of hydrogen peroxide and ascorbate was added to a final concentration of $100 \mu \mathrm{M}$. (A)

Represents the absorption spectra monitored every 15 s over $25 \mathrm{~min}$. Inset:
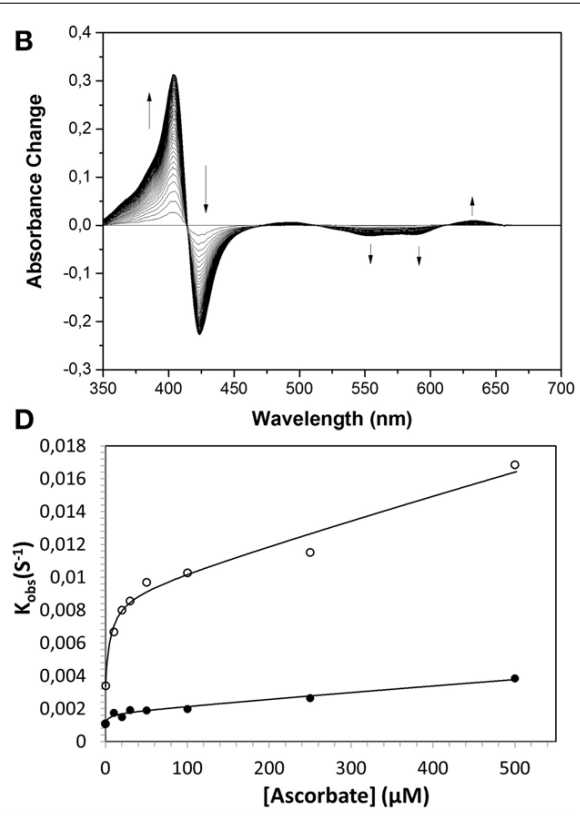

The time course of reaction at $405 \mathrm{~nm}$. (B) Shows spectra taken from (A) where the starting ferryl spectra have been set to zero. The rate constants for the two phases were determined by fitting the reaction time courses to a double exponential equation. (C): HbA, (D): HbF. The solid lines represent the double rectangular hyperbolic functions. Open symbols represent $\mathrm{Hb} \alpha$ subunit, and closed symbols represent $\mathrm{Hb} \beta$ subunit (or $\gamma$ subunit in $\mathrm{HbF}$ ). constant increased from $1.94 \times 10^{-3} \mathrm{~s}^{-1}$ to $1.35 \times 10^{-2} \mathrm{~s}^{-1}$ when the concentration of ascorbate was increased in the case of $\mathrm{HbA}$. A similar trend was observed for $\mathrm{HbF}$. The fast rate constant increased from $3.40 \times 10^{-3} \mathrm{~s}^{-1}$ to $1.69 \times 10^{-2} \mathrm{~s}^{-1}$ upon incremental additions of ascorbate from 0 to $500 \mu \mathrm{M}$. A difference in the high affinity pathway between these two hemoglobins can however, be observed; $\mathrm{HbF}$ has a lower $K_{D}$ value $(6 \mu \mathrm{M})$ than $\mathrm{HbA}\left(K_{D}=13 \mu \mathrm{M}\right)$. The auto-reduction rate constants, obtained when no ascorbate was added, were found to be $76 \%$ higher for $\mathrm{HbF}$ than $\mathrm{HbA}, 3.41 \times 10^{-3} \mathrm{~s}^{-} 1$ and $1.94 \times 10^{-3} \mathrm{~s}^{-1}$, respectively. The complete conversion of first oxidizing ferric $\mathrm{Hb}$ to the ferryl form with a low concentration of $\mathrm{H}_{2} \mathrm{O}_{2}$, followed by its auto-reduction is shown in Figure 4. Higher ferryl $\mathrm{Hb}$ levels are found for $\mathrm{HbA}$ at both ratios of heme to $\mathrm{H}_{2} \mathrm{O}_{2}$ tested, 1:1 and 1:2.

As described previously (Reeder et al., 2008a,b), the reduction of ferryl $\mathrm{Hb}$ embraces two alternative mechanisms, a high affinity pathway involving "a through-protein electron hopping mechanism" and a low affinity site involving a direct reduction of the ferryl iron, where ascorbate directly accesses the heme pocket. Since $\mathrm{HbA}$ and $\mathrm{HbF}$ carry the same $\alpha$ chains and since there are strong similarities between the $\beta$ and $\gamma$ chains, the reaction mechanisms are most likely analogous. However, when considering the low affinity site of the $\alpha$ chain reaction, it is obvious that there is a strong influence of the $\beta$ and $\gamma$ chains in the reduction pathway. The $K_{D}$ (estimated by fitting) at this site was found to be 6 and $10 \mathrm{mM}$ for $\mathrm{HbA}$ and $\mathrm{HbF}$, respectively. Similarly, the $k_{\max }$ was found to be $0.03 \mathrm{~s}^{-1}$ and $0.16 \mathrm{~s}^{-1}$ for $\mathrm{HbA}$ and $\mathrm{HbF}$, giving corresponding $k_{\max } / K_{D}$ values of 0.005 and $0.016 \mathrm{~s}^{-1} \mathrm{mM}^{-1}$. This implies that the efficiency of reduction using ascorbate is 3 -fold higher for $\mathrm{HbF}$ compared to $\mathrm{HbA}$. This in turn indicates that the heme pocket in $\mathrm{HbF}$ is most likely more accessible for ascorbate than the one in HbA.

Phosphatidylcholine liposomes were used as a model for studying the ability of $\mathrm{Hb}$ to induce lipid peroxidation. Ferrous and ferric $\mathrm{Hb}$ do not react with lipids, however, a lipid hydroperoxide $(\mathrm{LOOH})$, which is present in trace amounts in membranes or in a liposome preparation step can react. The reaction between ferric $\mathrm{Hb}\left(\mathrm{HbFe}^{3+}\right)$ and a lipid hydroperoxide ( $\left.\mathrm{LOOH}\right)$, yields ferryl $\mathrm{Hb}\left(\mathrm{HbFe}^{4+}\right)$ and a lipid alkoxyl radical (LO•) in the first step. The newly formed ferryl Hb can then be reduced back to ferric $\mathrm{Hb}$ by removal of hydrogen either from lipid ( $\mathrm{LH})$ or $\mathrm{LOOH}$

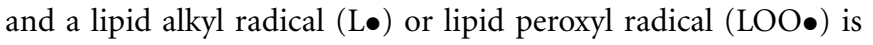
formed. In the presence of oxygen, the lipid alkyl radical will rapidly react to form a lipid peroxyl radical. The lipid oxidation started by ferric $\mathrm{Hb}$ is initially slow. However, when ferryl $\mathrm{Hb}$ and radical concentrations reach a critical point, a cascade of lipid peroxidation is started. This results in a rapid increase in the levels of lipid based conjugated dienes which can be followed spectrophotometrically at $234 \mathrm{~nm}$. Therefore, the time course of reaction is composed of a lag phase and a propagational part. The overall lipid oxidation cascade is presented in Equations (1-5).

$$
\begin{array}{r}
\mathrm{HbFe}^{3+}+\mathrm{LOOH} \longrightarrow \mathrm{HbFe}^{4+}-\mathrm{OH}-+\mathrm{LO} \bullet \\
(\text { starting reaction, lag phase) } \\
\mathrm{HbFe}^{4+}-\mathrm{OH}-+\mathrm{LH} \longrightarrow \mathrm{HbFe}^{3+}-\mathrm{H}_{2} \mathrm{O}+\mathrm{L} \bullet \\
(\text { propagational phase })
\end{array}
$$




$$
\begin{aligned}
& \mathrm{HbFe}^{4+}-\mathrm{OH}-+\mathrm{LOOH} \longrightarrow \mathrm{HbFe}^{3+}+\mathrm{LOO} \bullet+\mathrm{H}_{2} \mathrm{O} \\
& \quad(\text { propagational phase) } \\
& \mathrm{L} \bullet+\mathrm{O}_{2} \longrightarrow \mathrm{LOO} \bullet \\
& \mathrm{LH}+\mathrm{LOO} \bullet \longrightarrow \mathrm{L} \bullet+\mathrm{LOOH} \text { (propagational phase) }
\end{aligned}
$$

When comparing the lag phases, no difference was observed between $\mathrm{HbA}$ and $\mathrm{HbF}$. The typical lag phase was in the range of 2-4 min. However, a significant difference was observed in the propagational phase between the two Hbs. A maximum rate of conjugated diene formation was determined to be $1.31 \pm$ $0.09 \mu \mathrm{M} \mathrm{min}^{-1}$ for $\mathrm{HbA}$ and $1.07 \pm 0.06 \mu \mathrm{M} \mathrm{min}{ }^{-1}$ for $\mathrm{HbF}$ (Figure 5). In the presence of $2 \mu \mathrm{M}$ ascorbate, the maximum rates of diene formation were reduced to $1.24 \pm 0.10 \mu \mathrm{M} \mathrm{min}^{-1}$

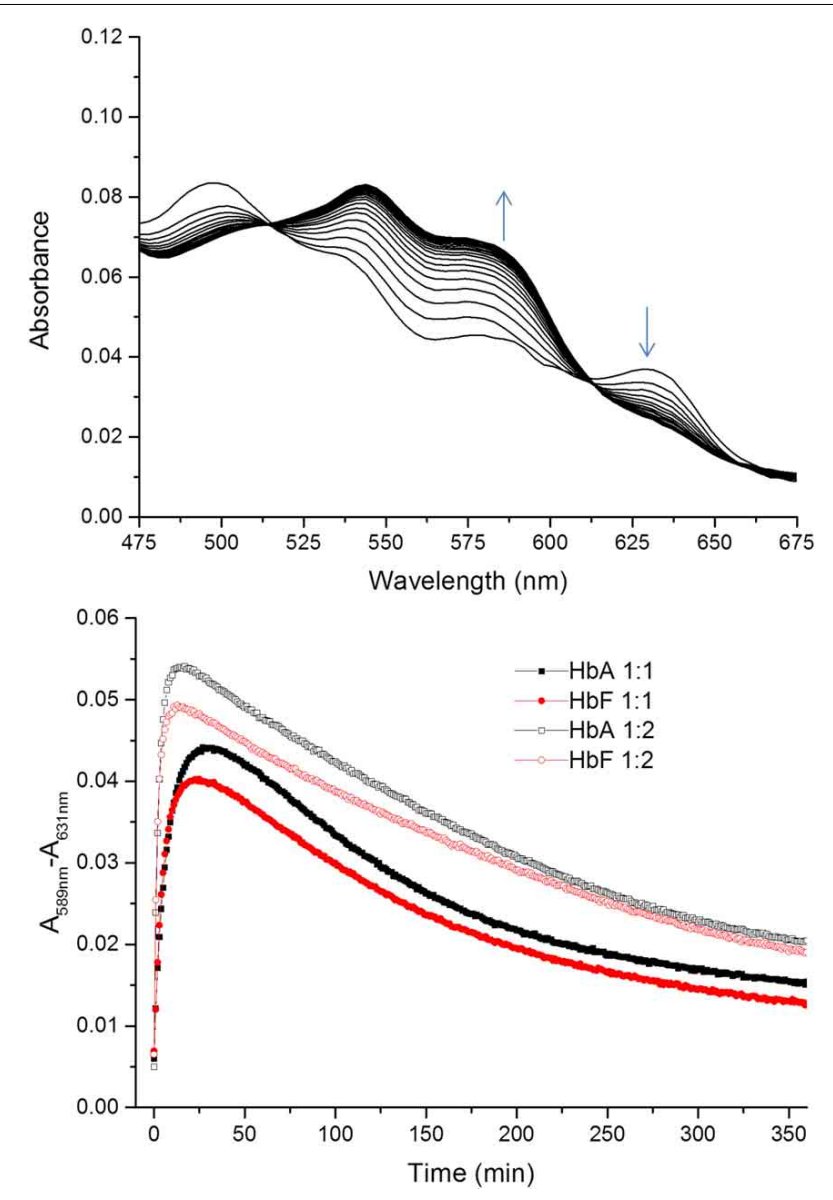

FIGURE 4 | Time courses for the reaction between ferric $\mathrm{Hb}$ and hydrogen peroxide. The spectra of the reactions were recorded every $1 \mathrm{~min}$ for $360 \mathrm{~min}$ within the $450-700 \mathrm{~nm}$ region. The upper figure shows a typical spectrum during the first 20 min of the reaction between ferric $\mathrm{HbF}$ and hydrogen peroxide. The appearance of ferryl $\mathrm{Hb}$ species $(589 \mathrm{~nm})$ and the decrease of ferric species $(631 \mathrm{~nm})$ are indicated with arrows. The lower part illustrates the differences in absorbance at 589-631 nm over time for the reaction between ferric $\mathrm{Hb}$ and hydrogen peroxide. Closed symbols represent the reaction when the $\mathrm{Hb}$ :hydrogen ratio is 1:1 and open symbols $1: 2$. Black and red represent the reactions of $\mathrm{HbA}$ and $\mathrm{HbF}$, respectively. and $1.01 \pm 0.13 \mu \mathrm{M} \mathrm{min}^{-1}$ for $\mathrm{HbA}$ and $\mathrm{HbF}$, respectively. In addition, the lag phases were extended to 6-8 $\mathrm{min}$. At a low concentration of ascorbate, the onset of reaction was thus delayed, but once the reaction was initiated, the rate of the reaction was the same as the rates without reductant.

Elevated levels of nitrite can promote the oxidation of $\mathrm{Hb}$. The reaction between oxyhemoglobin and nitrite was monitored by following the decrease in absorbance at $577 \mathrm{~nm}$. It was observed that $\mathrm{HbF}$ was oxidized to methemoglobin more rapidly than $\mathrm{HbA}$ with an excess of nitrite. $\mathrm{Hb}$ levels ranging between 5 and $40 \mu \mathrm{M}$ with $1 \mathrm{mM}$ nitrite were examined and the time needed to reach $50 \%$ conversion of the oxyHb levels, was defined as a half-time reaction value, or $t_{1 / 2}$, are shown in Figure 6. The $t_{1 / 2}$

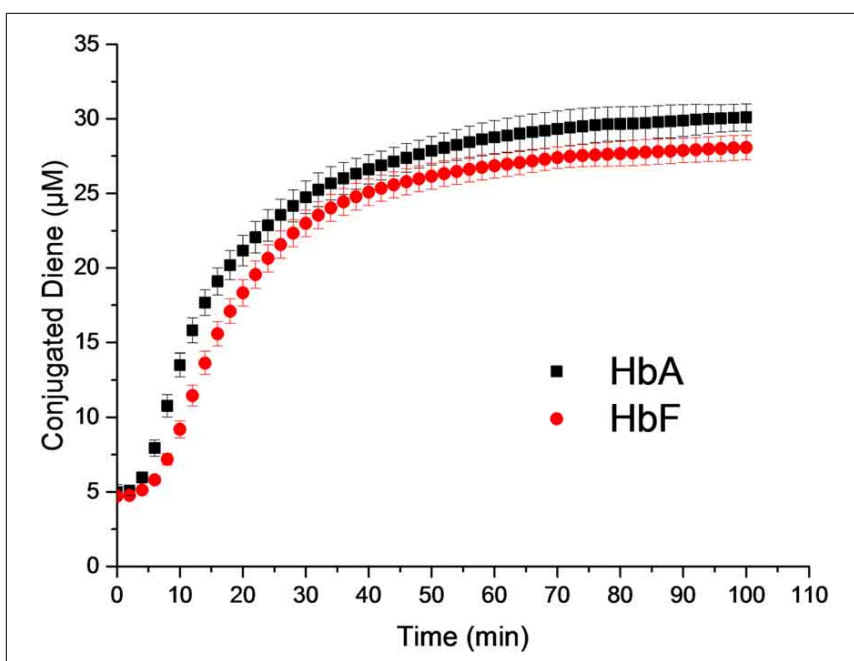

FIGURE $\mathbf{5}$ | Liposome oxidation by Hb. Conjugated diene formation over time was measured at $234 \mathrm{~nm}$.

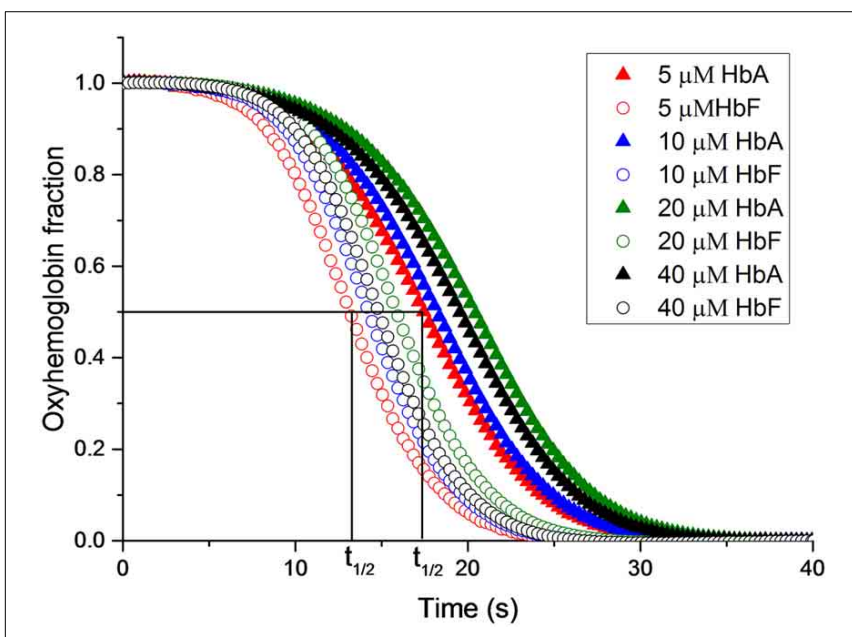

FIGURE 6 | The reaction between oxyhemoglobin and nitrite. Different oxyHb concentrations were incubated with $2 \mathrm{mM} \mathrm{NaNO}_{2}$. in $20 \mathrm{mM}$ sodium phosphate buffer buffer $\mathrm{pH} 7.4$ at $25^{\circ} \mathrm{C}$. The increments of oxyHb levels were monitored at at $577 \mathrm{~nm}$. The half-time of the reaction $\left(t_{1 / 2}\right)$ is indicated. 
values were on average $35 \%$ larger for $\mathrm{HbA}$ compared to $\mathrm{HbF}$. When following the reaction by monitoring overlaying spectra between 450 and $700 \mathrm{~nm}$, more detailed information about the intermediates of the reaction could be extracted (Figure 7). After mixing with nitrite, the oxidative status of $\mathrm{Hb}$ was therefore analyzed over a 5 -min period. For both $\mathrm{HbA}$ and $\mathrm{HbF}$, the reaction reached a final state with typical ferric hemoglobin spectra with peaks at approximately 500, 535, 575, and $630 \mathrm{~nm}$ (Figures 7A,B, $\mathrm{HbA}$ and $\mathrm{HbF}$, respectively). The spectra obtained over time were then analyzed by the CCA plus program to derive the composition of the ingoing spectral components during reaction (Figures 7C,D). The results of such an analysis are approximate, but under the conditions used, both hemoglobins generated the same final products. The first component is very similar to an oxyHb spectrum. Similarly, the final component gives an oxidized $\mathrm{Hb}$ spectrum. As described previously, the final products of reaction between oxyHb and nitrite are metHb and nitrate (Keszler et al., 2008). The component analysis also generated intermediate products which showed similarity with the partially oxidized $\mathrm{Hb}$, showing peaks at 500 and $630 \mathrm{~nm}$, and oxyHb characteristics, with peaks at 540 and $575 \mathrm{~nm}$. However, no clear evidence of an isosbestic point between 575 and $600 \mathrm{~nm}$ was observed. This indicated that there are more than two $\mathrm{Hb}$ populations present during the proceedings of the reaction. This is in agreement with a previous study, which also demonstrated that the major intermediate product of this reaction is ferryl Hb (Keszler et al., 2008).

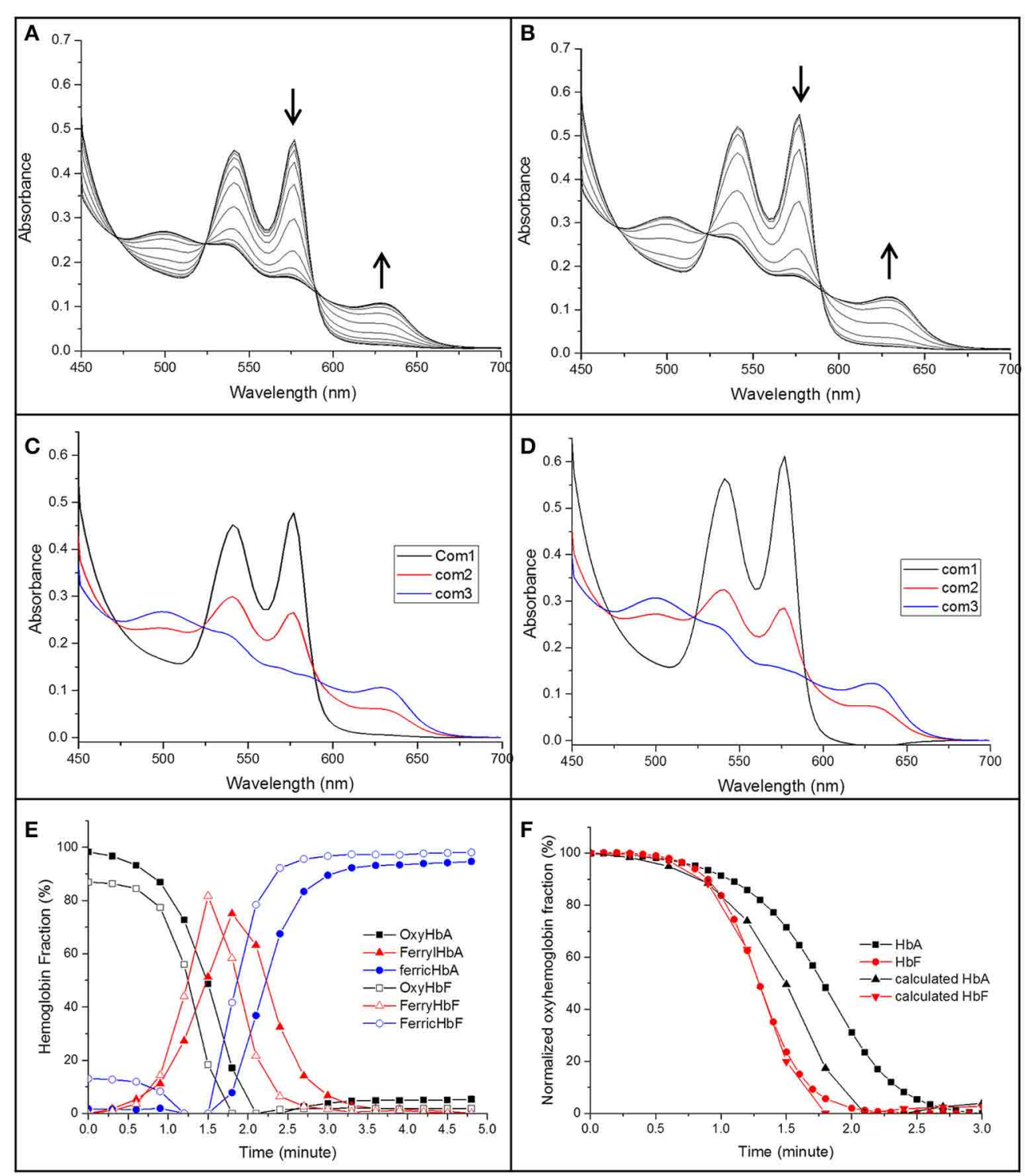

FIGURE 7| The spectra of the reaction between $40 \mu \mathrm{M}$ of oxyHb and $1 \mathrm{mM} \mathrm{NaNO} 2$ in $20 \mathrm{mM}$ sodium phosphate buffer buffer $\mathrm{pH} 7.4$ at $\mathbf{2 5}^{\circ} \mathbf{C}$ (A: HbA, B: HbF). The spectra were recorded in the $450-700 \mathrm{~nm}$ region every $18 \mathrm{~s}$. The decrease of $0 x y \mathrm{Hb}$ and the increase of ferric $\mathrm{Hb}$ during the reaction are indicated by arrows. A derived spectra component analysis from CCA plus is shown in (C,D) for $\mathrm{HbA}$ and $\mathrm{HbF}$, respectively, (E) gives an overview when a three component analysis were prepared. (F) Shows a comparison between the oxy $\mathrm{Hb}$ fraction calculated from the CCA plus program and a direct measurement of the absorbance at $577 \mathrm{~nm}$. 
By using this analysis, the presence of each component generated during the reaction could be compared for $\mathrm{HbA}$ and $\mathrm{HbF}$. As shown in Figure 7E, metHb was formed faster for $\mathrm{HbF}$ compared to HbA. When considering the reaction progress, both hemoglobins started to form the intermediate species at about the same time. However, the kinetics of the reaction was clearly different. In case of $\mathrm{HbF}$, the intermediate product was increased quickly and reached a maximum of about $80 \%$ at $1.5 \mathrm{~min}$, but was then fully removed after another $1.25 \mathrm{~min}$. HbA exhibited a significantly slower reaction progress, both in terms of intermediate formation and final removal. During the reaction with $\mathrm{HbA}$, the intermediate was thus accumulated and present over a longer time period compared with $\mathrm{HbF}$. When comparing the oxyHb fraction from the component analysis program with previous experiments where the conversion was followed at $577 \mathrm{~nm}$, the data from component analysis were identical to the experimental results for $\mathrm{HbF}$, but smaller deviations were observed for HbA (Figure 7F).
The reaction between $\mathrm{Hb}$ and nitrite is complex; un-identifiable $\mathrm{Hb}$ derivative spectra could be observed in the complex spectra. When examining the data by the CCA plus program with four component analysis, no improved fit was seen, clearly indicating that a more extensive characterization is needed to fully characterize the redox reaction.

In order to identify specific residues, or hotspots, in the $\beta$, $\gamma$, and $\alpha$ subunits of $\mathrm{HbA}$ and $\mathrm{HbF}$ that are prone to posttranslational oxidation upon $\mathrm{H}_{2} \mathrm{O}_{2}$ exposure, quantitative mass spectrometry was utilized to quantify all hotspot containing peptide and their corresponding charge states. Extracted ion chromatograms (XICs) were generated from the most abundant monoisotopic peak of each peptide isotopic profile (Figure 8) and the resulting ratio differences were compared for oxidized and unoxidized hotspot peptides (Table 1). For comparative purposes, we focused on residues that were conserved between $\gamma, \beta$, and $\alpha$ subunits for $\mathrm{HbF}$ and HbA. XICs were therefore

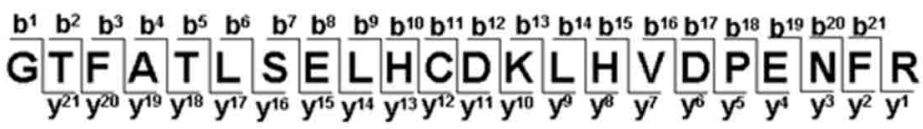

A

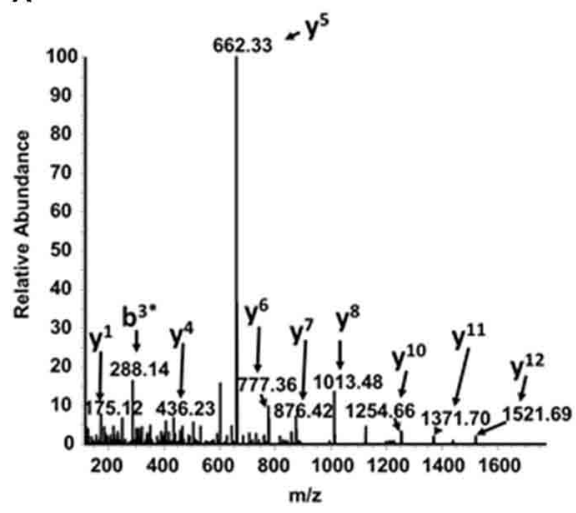

B

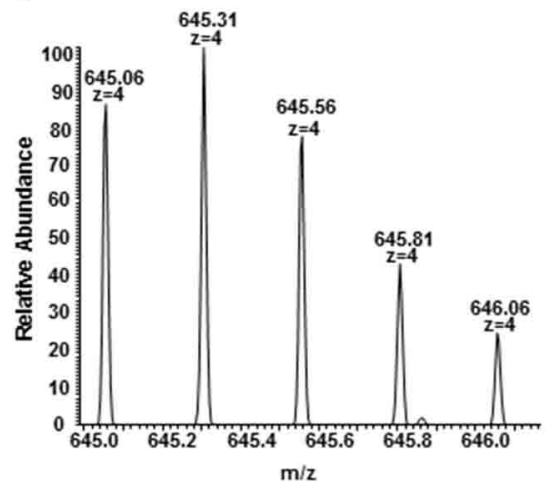

FIGURE 8 | MS/MS fragmentation spectrum and extracted ion chromatogram (XIC) of oxidized C93 tryptic peptide (residues 83-104). For quantitative experiments, all charged versions of Mascot identified peptides listed in Table 1 (containing the oxidized or unoxidized form) were selected in a similar manner as shown in this figure to quantify changes under different oxidative conditions. (A) Mascot identified MS/MS fragmentation spectrum of the oxidized C93 peptide GTFATLSELHCDKLHVDPENFR. (B,C) +4 and +3 charge state isotopic
C

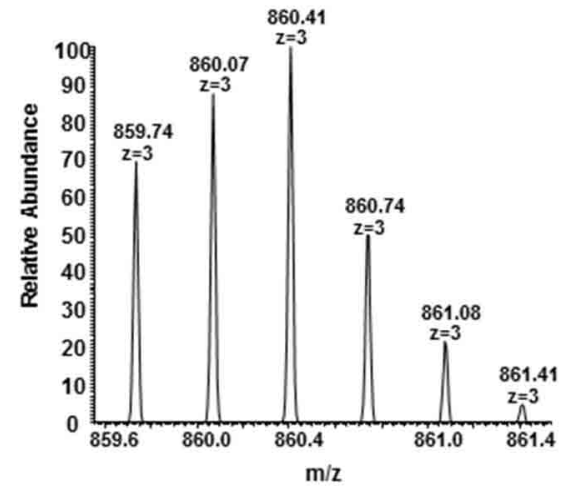

D

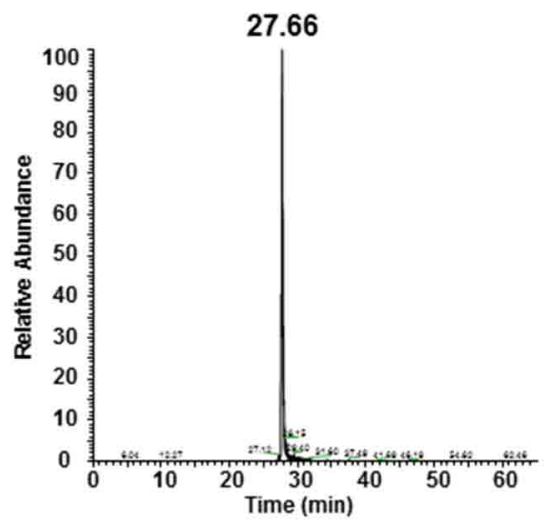

profiles of the oxidized C93 peptide GTFATLSELHCDKLHVDPENFR (residues 83-104). (D) Typical extracted ion chromatogram (XICs) for the oxidized C93 peptide (residues 83-104) generated from the ion current of the most abundant monoisotopic peak $(645.31 \mathrm{~m} / \mathrm{z})$ of the +4 charge state isotopic profile listed in (B) XICs, were generated for all bolded peptide sequences listed in Table 1. The ratio of each oxidized "hotspot" peptide was calculated based on the sum of the XIC peak area of all forms (oxidized and unmodified) to be $100 \%$. 
generated for the bolded peptide sequences in Table 1 representing conserved amino acids where significant differences in $\mathrm{H}_{2} \mathrm{O}_{2}$ induced oxidation were observed. For example, $\mathrm{C} 93$ is conserved in both $\gamma$ and $\beta$ subunits; the extent of $\mathrm{H}_{2} \mathrm{O}_{2}$ induced cysteine tri-oxidation was therefore monitored to identify how ferric $\mathrm{HbA}$ and $\mathrm{HbF}$ differ in their response to oxidative conditions. When analyzing the hotspot data shown in Table 2 , it is clear that $\beta$ subunits are more susceptible to oxidative changes than $\gamma$ subunits. These data showed substantial increases in $\mathrm{H}_{2} \mathrm{O}_{2}$ induced oxidation of $\beta$ C93 containing peptides for $\mathrm{HbA}$ compared to $\gamma \mathrm{C} 93$ for $\mathrm{HbF}$; for 300,400 , and $500 \mu \mathrm{M}$ there was a $\sim 20$ fold higher ratio of oxidized C93 for HbA vs. HbF. This suggests that the $\gamma$ subunit is considerably more stable or resistant to oxidation than the $\beta$ subunit of $\mathrm{HbA}$. It should also be pointed out that $\mathrm{HbA} \alpha$ subunits were slightly more oxidized than $\mathrm{HbF} \alpha$ subunits, although $\alpha$ oxidation (as observed for C104) for both hemoglobins was considerably low. This suggests that $\gamma$ may impose some level of additional stability in $\alpha$ subunits. Additionally, a higher level of nitrated $\beta$ Y35 containing peptides for HbA compared to $\gamma$ Y35 for $\mathrm{HbF}$ ( $\sim 30$ fold higher) was observed, which clearly supports the first data set indicating higher $\gamma$ subunit stability.

\section{DISCUSSION}

The overall three-dimensional structure of $\mathrm{HbF}$ is very similar to $\mathrm{HbA}$; however, differences in 39 amino acids of the gamma chain influence the physical and chemical properties of HbF. The major part of variation compared to $\mathrm{HbA}$ is found in the $\mathrm{N}$ terminal A helix where the $\gamma$ subunit differs from the $\beta$-subunit in 8 of 18 amino acid residues (Frier and Perutz, 1977). The role of the A helix is to maintain the tetrameric integrity of the $\mathrm{Hb}$ molecule, which is 70-fold stronger compared to HbA (Dumoulin et al., 1997; Yagami et al., 2002). The reduced tendency of HbF to dissociate into dimers has modified biophysical properties, and significant physiologic consequences. For instance, fetal red cells show enhanced resistance to the malaria parasite (Shear et al., 1998). Other substitutions, like the Glu43Asp replacement, which is located at the allosteric interface, together with the substitution of His143Ser at the DPG binding site, are critical in increasing oxygen affinity and facilitating a relevant physiological oxygen transfer from maternal to fetal blood (Chen et al., 2000). These substitutions could be part of a functional adaptation of $\mathrm{Hb}$ to allow its activity under conditions with lower oxygen levels. The fetus is largely developed under hypoxic conditions. Exposure to higher $\mathrm{O}_{2}$ concentrations at a later developmental stage or at childbirth, may lead to an escalation of oxidative stress levels. The presence of additional $\mathrm{H}_{2} \mathrm{O}_{2}$ during exposure to elevated oxygen levels can in turn trigger antioxidant enzyme systems, including catalase and glutathione peroxidase. However, $\mathrm{Hb}$ also exhibits an intrinsic peroxidase activity. This implies that $\mathrm{Hb}$ has a protective role against $\mathrm{H}_{2} \mathrm{O}_{2}$ which has been demonstrated in cell culture systems under oxidative stress (Widmer et al., 2009). As shown in this study, HbF carries a higher peroxidase activity which facilitates the removal of $\mathrm{H}_{2} \mathrm{O}_{2}$. Therefore, this activity may shield the fetus, both under normal physiological conditions and when impairment in the protective antioxidant enzyme systems has occurred.

Under normal physiological conditions, approximately $3 \%$ of $\mathrm{Hb}$ undergoes autoxidation to produce ferric $\mathrm{Hb}$. This process is accompanied by a release of $\mathrm{O}_{2}^{\bullet-}$ which rapidly dismutases to $\mathrm{H}_{2} \mathrm{O}_{2}$ by superoxide dismutase (SOD) (Johnson et al., 2005). The level of $\mathrm{H}_{2} \mathrm{O}_{2}$ in red blood cells is controlled by catalase and the concentration of $\mathrm{H}_{2} \mathrm{O}_{2}$ is relatively low, approximately $2 \times 10^{-10} \mathrm{M}$ (Giulivi et al., 1994). The $\mathrm{H}_{2} \mathrm{O}_{2}$ concentration in normal plasma is $4-5 \mu \mathrm{M}$ (Nagababu and Rifkind, 2000), however, these levels can increase as a result of a tissue injury, or under oxidative stress conditions. $\mathrm{H}_{2} \mathrm{O}_{2}$ is a reactive oxygen species which can cause damage to cells and tissues. $\mathrm{Hb}$ is also susceptible to $\mathrm{H}_{2} \mathrm{O}_{2}$ oxidation. The intermediate species of this reaction, ferryl $\mathrm{Hb}$, is considered to be as a very reactive species, however, the formed ferryl $\mathrm{Hb}$ decays rapidly, either through a comproportionation reaction with ferrous heme or through autoreduction to reform ferric Hb (Giulivi and Davies, 1990).

The oxidation of $\mathrm{Hb}$ by hydrogen peroxide can induce structural modifications on the globin molecule (Jia et al., 2007). Mass spectrometric approaches have thus previously revealed that cysteine amino acids are extensively oxidized to cysteic acid. Moreover, oxidation of these residues leads to a partial collapse of the $\beta$-chain. Effects of $\mathrm{H}_{2} \mathrm{O}_{2}$ on the $\alpha$-chain have also been observed, including the covalent linkage of the heme group to

Table 2 | Oxidative ratios for $\mathrm{C93}$ trioxidation of $10 \mu \mathrm{M}$ ferric $\mathrm{HbA}$ and $\mathrm{HbF}$ in the presence of $\mathrm{H}_{2} \mathrm{O}_{2}$ as well as nitration of $40 \mu \mathrm{M}$ ferrous $\mathrm{HbA}$ and $\mathrm{HbF}$ in the presence of sodium nitrite.

\begin{tabular}{|c|c|c|c|c|}
\hline Reaction condition & $\begin{array}{c}\text { C93 oxidation } \\
\% \mathrm{HbA} \beta\end{array}$ & $\begin{array}{l}\text { C93 oxidation } \\
\% \mathrm{HbF} \gamma\end{array}$ & $\begin{array}{l}\text { C104 oxidation } \\
\quad \% \mathrm{HbA} \alpha\end{array}$ & $\begin{array}{l}\text { C104 oxidation } \\
\% \mathrm{HbF} \alpha\end{array}$ \\
\hline no H2O2 & Trace & Below detection & $0.4 \pm 0.1 \%$ & $0.5 \pm 0.1 \%$ \\
\hline $200 \mu \mathrm{M} \mathrm{H} 202$ & $43 \pm 2.9 \%$ & $1.1 \pm 0.5 \%$ & $0.9 \pm 0.1 \%$ & $0.3 \pm 0.2 \%$ \\
\hline $300 \mu \mathrm{M} \mathrm{H} 202$ & $45 \pm 3.3 \%$ & $2.0 \pm 0.4 \%$ & $1.3 \pm 0.2 \%$ & $0.9 \pm 0.3 \%$ \\
\hline $400 \mu \mathrm{M} \mathrm{H} 202$ & $52 \pm 7.0 \%$ & $2.6 \pm 0.9 \%$ & $3.7 \pm 0.3 \%$ & $0.5 \pm 0.1 \%$ \\
\hline \multirow[t]{2}{*}{ Reaction condition } & Tyr 35 nitration & Tyr 35 Nitration & Tyr24 oxidation & Tyr24 oxidation \\
\hline & $\% \mathrm{HbA} \beta$ & $\% \mathrm{HbF} \gamma$ & $\% \mathrm{HbA} \alpha$ & $\% \mathrm{HbF} \alpha$ \\
\hline $40 \mu \mathrm{M}$ ferrous $\mathrm{HbA} / \mathrm{HbF} 1 \mathrm{mM}$ NaNO2 & $3.2 \pm 0.1 \%$ & $0.1 \pm 0.01 \%$ & $0.3 \pm 0.04 \%$ & $0.02 \% \pm 0.01$ \\
\hline
\end{tabular}


Ser-138. In this study, all identified peptides after treating with $\mathrm{H}_{2} \mathrm{O}_{2}$ are consistent with previous studies except at position 112 on the $\gamma$-chain of $\mathrm{HbF}$ which is substituted by threonine (Thr) and is thereby inert to $\mathrm{H}_{2} \mathrm{O}_{2}$ attack. The amino acids susceptible to $\mathrm{H}_{2} \mathrm{O}_{2}$ in the $\beta / \gamma$ chain (Cys and Met) are on the surface and are constantly exposed. In HbF, Thr112 is located on the $\alpha 1 \gamma 1$ interface. Modification of this residue could disturb subunit interactions within the $\mathrm{Hb}$ dimer leading to quaternary structural changes. However, after exposure to $\mathrm{H}_{2} \mathrm{O}_{2}$, this amino acid is not modified and the $\alpha 1 \gamma 1$ contact is still intact. This renders $\mathrm{HbF}$ more stable compared to $\mathrm{HbA}$. The peroxidase activity of ferric $\mathrm{Hb}$ and $\mathrm{H}_{2} \mathrm{O}_{2}$ results in the formation of higher oxidation species like ferryl $\mathrm{Hb}$ where the free radical may reside on $\beta$ Tyr -145 (Cooper et al., 2012). The stable HbF tetramer could prevent the intermolecular leakage of newly formed free radicals. Moreover, the distance from the center heme in the $\gamma$ chain to Tyr 145 is about $11 \AA$; this distance is within the range for electron transfer (Moser et al., 1992) and it then can be reused in a catalytic cycle. This might be the mechanism responsible for a higher autoreduction rate found in $\mathrm{HbF}$.

Both $\gamma$ and $\beta$ subunits share a common evolutionary ancestry, transcriptional control and thermodynamically exhibit a higher redox potential than $\alpha$ subunits (Strader et al., 2014). In fact, recent proteomic and crystal structures studies indicate that human $\alpha$ subunits from both wildtype and mutant $\mathrm{Hb}$ accumulate much smaller amounts of ferryl and ferryl protein radicals than $\gamma$ and $\beta$ subunits when exposed to $\mathrm{H}_{2} \mathrm{O}_{2}$ in solution (Strader et al., 2014). In this study, a fetal $\gamma$-globin mutation $(\gamma 67(\mathrm{E} 11) \mathrm{Val} \rightarrow \mathrm{Met})$ in which Met67 was post-translationally oxidized to aspartic acid (Asp) in blood from a newly born child, known as $\mathrm{Hb}$ Toms River. Under similar experimental oxidative conditions, (in the presence of increasing $\mathrm{H}_{2} \mathrm{O}_{2}$ ), the conversion of Met $\rightarrow$ Asp at position 67 in the $\beta$ subunits of recombinant adult Bristol $\mathrm{Hb}(\beta 67(\mathrm{E} 11) \mathrm{Val} \rightarrow \mathrm{Met})$, was also observed but not in the structurally equivalent $\alpha$ subunit variant (Hb Evans) ( $\alpha 62(\mathrm{E} 11) \mathrm{Val} \rightarrow \mathrm{Met})$. These findings confirm that a post-translational oxidative modification occurs within the redox active $\gamma$ or $\beta$ but not within $\alpha$ subunits of human $\mathrm{Hb}$ and correlate with the apparent differences in redox reactivity of $\mathrm{HbF}$ and $\mathrm{HbA}$ reported in this work.

The reaction between oxyHb and nitrite supports the hypothesis that $\mathrm{HbF}$ has a faster turnover rate. The reaction between oxyHb and nitrite starts slowly and $\mathrm{H}_{2} \mathrm{O}_{2}$ and metHb are produced in this step. The reaction is then accelerated by the fast conversion of metHb by the newly formed $\mathrm{H}_{2} \mathrm{O}_{2}$ generating ferryl $\mathrm{Hb}$ as an intermediate species. Ferryl $\mathrm{Hb}$, however, can be reduced quickly with nitrite to yield a metHb and a nitrite radical which then can react directly with oxyHb to generate nitrate. The overall reaction hence produces metHb and nitrate. In $\mathrm{HbF}$, the intermediate species of the reaction, ferryl $\mathrm{Hb}$, is converted back more quickly to metHb than $\mathrm{HbA}$ thereby preventing an accumulation of the more toxic ferryl $\mathrm{Hb}$ in the system. In human red blood cells, metHb is then converted to ferrous $\mathrm{Hb}$ by methemoglobin reductase. The lower lipid oxidation rate observed for the $\mathrm{HbF}$ reaction in the liposome oxidation study also supports that a faster ferric-ferryl $\mathrm{Hb}$ redox cycle could be a benefit especially under a reducing environment.
In summary, we propose that having different $\mathrm{Hb}$ molecules in each stage of fetal development is not only an adaptation for efficient oxygen transfer to the fetus, but it also involves a protection against reactive oxygen species. Moreover, the ability of $\mathrm{HbF}$ to remove $\mathrm{H}_{2} \mathrm{O}_{2}$ faster compared to $\mathrm{HbA}$, which together with a higher structural stability could be used as strategies for an improved design of HBOCs. A previous study also suggests that deoxy $\mathrm{HbF}$ exhibits a higher nitrite reductase activity (Blood et al., 2009). Therefore, it can produce NO in the presence of nitrite. As suggested earlier, the toxicity of $\mathrm{Hb}$ can be further ameliorated by modulating the electron transfer pathway to enhance removal of the toxic ferryl $\mathrm{Hb}$ (Reeder et al., 2008a). HbF may be particularly useful as starting material for HBOC applications, since it produces lower levels of ferryl $\mathrm{Hb}$, and the ferryl form can be readily reduced back to ferric $\mathrm{Hb}$ by antioxidants found in human circulation.

\section{ACKNOWLEDGMENTS}

We wish to acknowledge the financial support from the Swedish Science Foundation and the Swedish Foundation for Strategic Research as well as a Royal Thai Government Scholarship (to KR). We also thank Cedric Dicko for constructive discussions on the kinetic evaluations. This work was also supported by National Institutes of Health Grant P01-HL110900 from NHLBI (AIA.) and by United States Food and Drug Administration Grants MODSCI (AIA).

\section{REFERENCES}

Akinsheye, I., Alsultan, A., Solovieff, N., Ngo, D., Baldwin, C. T., Sebastiani, P., et al. (2011). Fetal hemoglobin in sickle cell anemia. Blood 118, 19-27. doi: 10.1182/blood-2011-03-325258

Alayash, A. I. (2004). Oxygen therapuetics: can we tame haemoglobin? Nat. Rev. Drug Discov. 3, 152-159. doi: 10.1038/nrd1307

Alayash, A. I. (2014). Blood substitutes: why haven't we been more successful? Trends Biotechnol. 32, 177-185. doi: 10.1016/j.tibtech.2014.02.006

Anderson, U. D., Olsson, M. G., Kristensen, K. H., Åkerström, B., and Hansson, S. R. (2012). Review: biochemical markers to predict preeclampsia. Placenta 33(Suppl.), S42-S47. doi: 10.1016/j.placenta.2011.11.021

Baek, J. H., D’Agnillo, F., Vallelian, F., Pereira, C. P., Williams, M. C., Jia, Y., et al. (2012). Hemoglobin-driven pathophysiology is an in vivo consequence of the red blood cell storage lesion that can be attenuated in guinea pigs by haptoglobin therapy. J. Clin. Invest. 122, 1448-1458. doi: 10.1172/JCI59770

Belcher, J. D., Chen, C., Nguyen, J., Milbauer, L., Abdulla, F., Alayash, A. I., et al. (2014). Heme Triggers TLR4 signaling leading to endothelial cell activation and vaso-occlusion in murine sickle cell disease. Blood 123, 377-390. doi: 10.1182/blood-2013-04-495887

Bianci, N., Zuccato, C., Lampronti, I., Borgatti, M., and Gambari, R. (2007). Fetal Hemoglobin Inducers from the natural world: a novel approach for indeitifcation of drugs for the treatment of $\beta$-thalassemia and sickle cell anemia. Evid. Based Complement. Alternat. Med. 6, 141-151. doi: 10.1093/ecam/nem139

Blood, A. B., Tiso, M., Verma, S. T., Lo, J., Joshi, M. S., Azarov, I., et al. (2009). Increased nitrite reductase activity of fetal versus adult ovine hemoglobin. Am. J. Physiol. 296, H237-H246. doi: 10.1152/ajpheart.00601.2008

Chen, W., Dumoulin, A., Li, X., Padovan, J. C., Chait, B. T., Buonopane, R., et al. (2000). Transposing sequences between fetal and adult hemoglobins indicates which subunits and regulatory molecule interfaces are functionally related $\dagger$. Biochemistry 39, 3774-3781. doi: 10.1021/bi9926911

Cooper, C. E., Schaer, D. J., Buehler, P. W., Wilson, M. T., Reeder, B. J., Silkstone, G., et al. (2012). Haptoglobin binding stabilizes hemoglobin ferryl iron and the globin radical on Tyrosine $\beta 145$. Antioxid. Redox Signal. 18, 2264-2273. doi: 10.1089/ars.2012.4547.test

Dumoulin, A., Manning, L. R., Jenkins, W. T., Winslow, R. M., and Manning, J. M. (1997). Exchange of subunit interfaces between recombinant adult and fetal 
hemoglobins: evidence for a functional inter-relationship among regions of the tetramer. J. Biol. Chem. 272, 31326-31332. doi: 10.1074/jbc.272.50.31326

Egmond, M. R., Brunori, M., and Fasella, P. M. (1976). The steady-state kinetics of the oxygenation of linoleic acid catalysed by soybean lipoxygenase. Eur. J. Biochem. 61, 93-100. doi: 10.1111/j.1432-1033.1976.tb10001.x

Engel, R. R., Rodkey, F. L., O’Neal, J. D., and Collison, H. A. (1969). Relative affinity of human fetal hemoglobin for carbon monoxide and oxygen. Blood 33, 37-45.

Forget, B. G. (1998). Molecular basis of hereditary persistence of fetal hemoglobin. Ann. N.Y. Acad. Sci. 850, 38-44. doi: 10.1111/j.1749-6632.1998.tb10460.x

Frier, J. A., and Perutz, M. F. (1977). Structure of human foetal deoxyhaemoglobin. J. Mol. Biol. 112, 97-112. doi: 10.1016/S0022-2836(77)80158-7

Giulivi, C., and Davies, K. J. (1990). A novel antioxidant role for hemoglobin. The comproportionation of ferrylhemoglobin with oxyhemoglobin. J. Biol. Chem. $265,19453-19460$.

Giulivi, C., Hochstein, P., and Davies, K. J. A. (1994). Hydrogen peroxide production by red blood cells. Free Radic. Biol. Med. 16, 123-129. doi: 10.1016/08915849(94)90249-6

Hofmann, O., and Brittain, T. (1996). Ligand binding kinetics and dissociation of the human embryonic haemoglobins. Biochem. J. 315, 65-70.

Jia, Y., Buehler, P. W., Boykins, R. A., Venable, R. M., and Alayash, A. I. (2007). Structural basis of peroxide-mediated changes in human hemoglobin: a novel oxidative pathway. J. Biol. Chem. 282, 4894-4907. doi: 10.1074/jbc.M609955200

Johnson, R. M., Goyette, G. Jr., Ravindranath, Y., and Ho, Y.-S. (2005). Hemoglobin autoxidation and regulation of endogenous $\mathrm{H} 2 \mathrm{O} 2$ levels in erythrocytes. Free Radic. Biol. Med. 39, 1407-1417. doi: 10.1016/j.freeradbiomed.2005.07.002

Keller, A., Nesvizhskii, A. I., Kolker, E., and Aebersold, R. (2002). Empirical statistical model to estimate the accuracy of peptide identifications made by MS/MS and database search. Anal. Chem. 74, 5383-5392. doi: 10.1021/ac025747h

Keszler, A., Piknova, B., Schechter, A. N., and Hogg, N. (2008). The reaction between nitrite and oxyhemoglobin: a mechanistic study. J. Biol. Chem. 283, 9615-9622. doi: 10.1074/jbc.M705630200

Kvist, M., Ryabova, E. S., Nordlander, E., and Bulow, L. (2007). An investigation of the peroxidase activity of Vitreoscilla hemoglobin. J. Biol. Inorg. Chem. 12, 324-334. doi: 10.1007/s00775-006-0190-x

Lebensburger, J., Johnson, S. M., Askenazi, D. J., Rozario, N. L., Howard, T. H., and Hilliard, L. M. (2011). Protective role of hemoglobin and fetal hemoglobin in early kidney disease for children with sickle cell anemia. Am. J. Hematol. 86, 430-432. doi: 10.1002/ajh.21994

Manca, L., and Masala, B. (2008). Disorders of the synthesis of human fetal hemoglobin. IUBMB Life 60, 94-111. doi: 10.1002/iub.4

Mollan, T. L., Banerjee, S., Wu, G., Siburt, C. J. P., Tsai, A.-L., Olson, J. S., et al. (2013). Alpha-hemoglobin stabilizing protein (AHSP) markedly decreases the redox potential and reactivity of alpha subunits of human $\mathrm{HbA}$ with hydrogen peroxide. J. Biol. Chem. 288, 4288-4289. doi: 10.1074/jbc.M112.412064

Moser, C. C., Keske, J. M., Warncke, K., Farid, R. S., and Dutton, P. L. (1992). Nature of biological electron transfer. Nature 355, 796-802. doi: 10.1038/355796a0

Nagababu, E., and Rifkind, J. M. (2000). Reaction of Hydrogen Peroxide with Ferrylhemoglobin: superoxide production and heme degradation. Biochemistry 39, 12503-12511. doi: 10.1021/bi992170y

Nesvizhskii, A. I., Keller, A., Kolker, E., and Aebersold, R. (2003). A statistical model for identifying proteins by tandem mass spectrometry. Anal. Chem. 75, 4648-4658. doi: 10.1021/ac0341261

Olsson, M. G., Centlow, M., Rutardóttir, S., Stenfors, I., Larsson, J., Hosseini-Maaf, B., et al. (2010). Increased levels of cell-free hemoglobin, oxidation markers, and the antioxidative heme scavenger $\alpha 1$-microglobulin in preeclampsia. Free Radic. Biol. Med. 48, 284-291. doi: 10.1016/j.freeradbiomed.2009.10.052

Olsson, M. G., Allhorn, M., Bulow, L., Hansson, S. R., Ley, D., Olsson, M. L., et al. (2012). Pathological conditions involving extracellular hemoglobin: molecular mechanisms, clinical significance, and novel therapeutic opportunities for $\alpha(1)$ microglobulin. Antioxid. Redox Signal. 17, 813-846. doi: 10.1089/ars.2011.4282

Perczel, A. S., Hollósi, M., Tusn'dy, G. B., and Fasman, G. D. (1991). Convex constraint analysis: a natural deconvolution of circular dichroism curves of proteins. Protein Eng. 4, 669-679. doi: 10.1093/protein/4.6.669
Pimenova, T., Pereira, C. P., Gehrig, P., Bueler, P. W., Schaer, D. J., and Zenobi, R. (2010). Quantitative mass spectrometry defines an oxidative hotspot in hemoglobin that is specifically protected by haptoglobin. J. Proteome Res. 9, 4061-4070. doi: 10.1021/pr100252e

Reeder, B. J. (2010). The redox activity of hemoglobins: from physiologic functions to pathologic mechanisms. Antioxid. Redox Signal. 13, 1087-1123. doi: 10.1089/ars.2009.2974

Reeder, B. J., Cutruzzola, F., Bigotti, M. G., Hider, R. C., and Wilson, M. T. (2008b). Tyrosine as a redox-active center in electron transfer to ferryl heme in globins. Free Radic. Biol. Med. 44, 274-283. doi: 10.1016/j.freeradbiomed.2007. 06.030

Reeder, B. J., Grey, M., Silaghi-Dumitrescu, R.-L., Svistunenko, D. A., Bülow, L., Cooper, C. E., et al. (2008a). Tyrosine residues as redox cofactors in human hemoglobin: implications for engineering nontoxic blood substitutes. J. Biol. Chem. 283, 30780-30787. doi: 10.1074/jbc.M804709200

Risso, A., Fabbro, D., Damante, G., and Antonutto, G. (2012). Expression of fetal hemoglobin in adult humans exposed to high altitude hypoxia. Blood Cells Mol. Dis. 48, 147-153. doi: 10.1016/j.bcmd.2011.12.004

Shear, H. L., Grinberg, L., Gilman, J., Fabry, M. E., Stamatoyannopoulos, G., Goldberg, D. E., et al. (1998). Transgenic mice expressing human fetal globin are protected from malaria by a novel mechanism. Blood 92, 2520-2526.

Snell, S. M., and Marini, M. A. (1988). A convenient spectroscopic method for the estimation of hemoglobin concentrations in cell-free solutions. J. Biochem. Biophys. Methods 17, 25-33. doi: 10.1016/0165-022X(88)90075-9

Strader, M. B., Hicks, W. A., Kassa, T., Singleton, E., Soman, J., Olson, J. S., et al. (2014). Post-translational transformation of methionine to aspartate is catalyzed by heme iron and driven by peroxide: a novel subunitspecific mechanism in hemoglobin. J. Biol. Chem. 289, 22342-22357. doi: $10.1074 /$ jbc.M114.568980

Stubbe, J., and Riggs-Gelasco, P. (1998). Harnessing free radicals: formationand function of the tyrosyl radical in ribonucleotide reductase. Trends Biochem. Sci. 23, 438-443. doi: 10.1016/S0968-0004(98)01296-1

Vandegriff, K. D., Malavalli, A., Minn, C., Jiang, E., Lohman, J., Young, M. A., et al. (2006). Oxidation and haem loss kinetics of poly(ethylene glycol)-conjugated haemoglobin (MP4): dissociation between in vitro and in vivo oxidation rates. Biochem. J. 399, 463-471. doi: 10.1042/BJ20060809

Widmer, C. C., Pereira, C. P., Gehrig, P., Vallelian, F., Schoedon, G., Buehler, P. W., et al. (2009). Hemoglobin can attenuatehydrogen peroxide-induced oxidative stress by acting as an antioxidative peroxidase. Antioxid. Redox Signal. 12, 185-198. doi: 10.1089/ars.2009.2826

Yagami, T., Ballard, B. T., Padovan, J. C., Chait, B. T., Popowicz, A. M., and Manning, J. M. (2002). N-terminal contributions of the $\gamma$-subunit of fetal hemoglobin to its tetramer strength: remote effects at subunit contacts. Protein Sci. 11, 27-35. doi: 10.1110/ps.ps.30602

Conflict of Interest Statement: The authors declare that the research was conducted in the absence of any commercial or financial relationships that could be construed as a potential conflict of interest.

Received: 30 October 2014; accepted: 27 January 2015; published online: 20 February 2015.

Citation: Ratanasopa K, Strader MB, Alayash AI and Bulow L (2015) Dissection of the radical reactions linked to fetal hemoglobin reveals enhanced pseudoperoxidase activity. Front. Physiol. 6:39. doi: 10.3389/fphys.2015.00039

This article was submitted to Oxidant Physiology, a section of the journal Frontiers in Physiology.

Copyright (c) 2015 Ratanasopa, Strader, Alayash and Bulow. This is an open-access article distributed under the terms of the Creative Commons Attribution License (CC BY). The use, distribution or reproduction in other forums is permitted, provided the original author(s) or licensor are credited and that the original publication in this journal is cited, in accordance with accepted academic practice. No use, distribution or reproduction is permitted which does not comply with these terms. 